Pesq. Vet. Bras. 36(6):479-484, junho 2016 DOI: $10.1590 / \mathrm{S} 0100-736 \mathrm{X} 2016000600004$

\title{
Genetic relationship between Escherichia coli strains isolated from dairy mastitis and from the stable fly Stomoxys calcitrans ${ }^{1}$
}

\author{
Bruno G. Castro ${ }^{2 *}$, Miliane M.S. Souza ${ }^{3}$, Adriana H. Regua-Mangia ${ }^{4}$ \\ and Avelino J. Bittencourt ${ }^{3}$
}

\begin{abstract}
Castro B.G., Souza M.M.S., Regua-Mangia A.H. \& Bittencourt A.J. 2016. Genetic relationship between Escherichia coli strains isolated from dairy mastitis and from the stable fly Stomoxys calcitrans. Pesquisa Veterinária Brasileira 36(6):479-484. Universidade Federal de Mato Grosso, Campus Universitário de Sinop, Av. Alexandre Ferronato 1200B, Setor Industrial, Sinop, MT 78557-270, Brazil. E-mail: castrobg@ufmt.br

The stable fly Stomoxys calcitrans (Linnaeus, 1758) has been described as a potential spreader of infectious agents to cattle herds. Among the agents transmitted by this fly, Escherichia coli has attracted attention due to its potential to cause gastrointestinal disorders as well as environmental mastitis in dairy cows. Therefore, the aim of this study was to isolate and to assess the genetic diversity and the clonal relatedness among E. coli isolates from the milk of dairy mastitis and from stable flies anatomical sites by the Random Amplification of Polymorphic DNA (RAPD-PCR) technique. The molecular typing revealed a high degree of genetic polymorphism suggesting that these microorganisms have a non-clonal origin. Identical electrophoretic profiles were observed between E. coli isolates from different flies, different mammary quarters of the same cow and from cows on a single farm. These results reveal the circulation of the same bacterial lineages and suggest the role of the stable fly in bacterial dispersion. Considering the high pathogenic potential of this bacterial species, our findings alert to a more effective health surveillance.
\end{abstract}

INDEX TERMS: Random amplification of polymorphic DNA, RAPD, milk, stable fly, clonal species.

RESUMO.- [Caracterização genotípica de Escherichia coli isolados de leite com mastite e da mosca dos estábulos Stomoxys calcitrans.] A mosca dos estábulos Stomoxys calcitrans é descrita como um importante dispersor de agentes infecciosos aos bovinos. Dentre os agentes veiculados por esta mosca a bactéria Escherichia coli ganha relevância devido ao seu potencial em desenvolver alterações gastroentéricas, bem como mastite bovina ambiental. Desta forma, objetiva-se com este estudo isolar e acessar a diversidade genética e relação de clonalidade entre isolados de E. coli provenientes de casos de mastite e de moscas dos estábulos utilizando a técnica da Amplificação Randô-

\footnotetext{
${ }^{1}$ Received on August 21, 2015.

Accepted for publication on April 1, 2016.

${ }^{2}$ Universidade Federal de Mato Grosso (UFMT), Campus Universitário de Sinop, Av. Alexandre Ferronato 1200B, Setor Industrial, Sinop, MT 78557-270, Brazil. *Corresponding author: castrobg@ufmt.br

${ }^{3}$ Instituto de Veterinária, Universidade Federal Rural do Rio de Janeiro (UFRRJ), BR-465, Km 7, Seropédica, RJ 23890-000, Brazil.

${ }^{4}$ Escola Nacional de Saúde Pública Sergio Arouca, Fundação Oswaldo Cruz (Fiocruz), Rua Leopoldo Bulhões 1480, Manguinhos, Rio de Janeiro, RJ 21041-210, Brazil.
}

mica do DNA Polimórfico (RAPD). A tipagem molecular revelou elevado polimorfismo genético sugerindo que esses microrganismos têm origem não clonal. Perfis eletroforéticos idênticos entre si foram observados entre amostras isoladas de diferentes moscas, quartos mamários de uma mesma vaca, bem como de diferentes vacas dentro de uma mesma propriedade. Esses resultados revelam a circulação de uma mesma linhagem bacteriana e sugerem o papel da Stomoxys calcitrans na dispersão bacteriana. Considerando o elevado potencial patogênico dessa espécie bacteriana, nossos achados alertam para uma vigilância sanitária mais efetiva.

TERMOS DE INDEXAÇÃO: Amplificação randômica do DNA polimórfico, RAPD, leite, mosca dos estábulos, clones.

\section{INTRODUCTION}

Despite the reduction in the number of cases of bovine mastitis of contagious origin in the world, several authors have reported that cases of environmental origin have been increasing, mainly caused by Escherichia coli (Fairbrother et al. 2015). The proportion of E. coli isolated as an etiolo- 
gical agent from the milk of cows suffering from mastitis varies according to the place of study. According to Nevala et al. (2004), in Finland fewer than $20 \%$ of mastitis cases are caused by E. coli, while Shpigel et al. (1998) and Shpigel et al. (2008) reported $60 \%$ in Israel, as well as the E. coli is the leading cause of acute mastitis in dairy animals in that country. In Brazil the cases of mastitis caused by E. coli have a prevalence ranging from $4.0 \%$ to $15 \%$, possibly due to the stock-raising system used in the country, where the animals generally are confined to stables only at the time of milking, thus reducing the possibility of contaminating the mammary quarters by feces (Ferreira et al. 2007).

Hyper-acute and acute udder infections by E. coli occur in the first weeks of clinical and sub-clinical form. They are difficult to cure therapeutically, and cases of systemic involvement can lead to death by toxemia (Hertl et al. 2010). The main source of contamination is by direct contact of the recently milked mammary quarters with materials contaminated by the agent, such as feces, unhygienic equipment, dirty hands of stable workers and possibly some insects, as muscid flies (Pyörälä 2002, Ryman et al. 2013).

Some muscid flies have been studied for their potential to transmit agents causing mastitis. Among these, the flies Hydrotea irritans, Haematobia irritans and Musca domesti$c a$ are most often studied in Europe and USA and have been implicated on carriage of bacterial mastitis strains in experimental cases (Chirico et al. 1997, Braverman et al. 1999, Anderson et al. 2012).

The stable fly has also been studied among the Muscidae family causing injury to Brazilian cattle herds. Some authors have found similarity in the isolation of agents from cases of bovine mastitis and in Stomoxys calcitrans (Castro et al. 2001, Moraes et al. 2004). However, these authors did not confirm the real potential of stable flies to transmit agents of bovine mastitis; they only reported the possibility of this occurrence.

This study was designed to isolate and to assess the genetic diversity among E. coli isolates from mastitic milk of dairy cattle and stable fly from dairy farms in Rio de Janeiro state.

\section{MATERIALS AND METHODS}

For this study 10 dairy farms in the municipalities of Barra Mansa and Resende located at Rio de Janeiro state, Brazil, were visited. These two municipalities were selected because these locations are the main dairy region of the state of Rio de Janeiro (IBGE 2009). Also, previous studies detected a high prevalence of the stable fly and in these municipalities it was identified common bacterial species from the microbiota of macerated flies and mastitic milk, but the genetic relationship was not evaluated (Castro et al. 2001, Moraes et al. 2004).

At the visited farms, the cows ready for milking were submitted to the California Mastitis Test (CMT). After detected the positive quarters, milk samples were taken from these after washing the teats with neutral soap and water and then drying and disinfecting them with iodized alcohol. The milk samples were placed in sterile tubes and taken under refrigeration to the laboratory for bacterial isolation.

Twenty flies were also collected at each farm, using an insect sweep net, giving preference to those that were feeding or flying at most one half meter from the animals (Bramley et al. 1985, Puri-Giri et al. 2015). Each fly was placed in a sterile test tube and taken under refrigeration to the laboratory.

All the dissection procedures of the flies were performed under a fume hood near a Bunsen burner. The flies were identified according to Bowman (2014), and only the S. calcitrans specimens were killed by freezing at $-10^{\circ} \mathrm{C}$ for five minutes. Then, each frozen fly was placed in a test tube containing enriched brain-heart infusion (BHI) Broth, agitated in this tube and transferred to another test tube containing 70\% alcohol for 10 minutes for sterilization of the outer surface, as described by Hillerton \& Bramley (1985) and Castro et al. (2013).

Then each fly was placed on its back in a sterile Petri dish and a stereoscopic microscope was used to aid removal of the mouth apparatus and abdominal digestive tract, as described by Castro et al. (2007). Each segment was then macerated in BHI Broth and incubated in a bacteriological chamber at $37^{\circ} \mathrm{C}$ for at least 24 hours.

After the incubation period, the samples were transferred to Petri dishes containing the MacConkey agar and Eosin Methyl Blue (EMB) agar. The colonies were then observed regarding morphological and physiological characteristics. After differentiation of the typical E.coli colonies, a preliminary identification assays was carried out: Gram staining and the hydrolysis test to $3 \% \mathrm{KOH}$ to confirm the Gram catalysis test. Putative Escherichia coli colonies were confirmed biochemically and the following identification tests were conducted: behavior in triple sugar iron agar; behavior in SIM agar; production of acids by glycolysis; sugar fermentation; Voges Proskauer (VP) test; methyl red (MR) test; nitrate reduction; galatinase production; citrate and malonate degradation; and other differential tests according to the microorganism involved (Koneman et al. 2008).

E. coli was stored frozen for further genetic analysis. Prior to use, each isolate was streaked onto Trypticase Soy Agar (TSA; $\mathrm{BBL}$ ) and grown overnight at $37^{\circ} \mathrm{C}$ for analysis of purity and viability. The genetic diversity was investigated by RAPD-PCR according to the methodology described by Pacheco et al. (1997) and Vogel et al. (2000).

For the bacterial typing, a colony of $E$. coli was incubated in Trypticase Soy Broth (TSB - BBL Microbiology Systems, Cockeysville, MD) at $37^{\circ} \mathrm{C}$. After $18-24$ hours, an aliquot of the bacterial culture was diluted 1:10 in water immediately before use to determine the optical density at $600 \mathrm{~nm}$. For an optical density value of 0.4 , a $200-\mu \mathrm{l}$ aliquot of the stationary-phase culture was centrifuged (12,000 $3 \mathrm{~g}$ for $2 \mathrm{~min}$ ) and suspended in $900 \mu \mathrm{l}$ of sterile distilled water. The suspension was then boiled for 10 min, briefly centrifuged, and the bacterial lysate was used as the template source in amplification assays. RAPD reactions were carried out with six 10-mer primers: 1247 (5'-AAGAGCCCGT-3'), 1253 (5'-GTTTCCGCCC-3'), 1281 (5'-AACGCGCAAC-3'), 1254 (5'-CCGCAGCCAA-3'), M13 (5'-GAGGGTGGCGGTTCT-3'), and A04 (5'-AATCGGGCTG-3'). A volume of $3 \mu \mathrm{L}$ of the DNA template together with other reagents: $20 \mathrm{mM}$ of Tris- $\mathrm{HCl}$ (pH 8.4) (Fermentas, Burlington, Canada), $50 \mathrm{mM}$ of $\mathrm{HCl}, 4 \mathrm{mM}$ of $\mathrm{MgCl}_{2}$ (Fermentas, Burlington, Canada), $250 \mu \mathrm{M}$ (each) of dNTP (ABgene, Epsom, $\mathrm{UK}), 30 \mathrm{pmol} / \mu \mathrm{l}$ of primer and $1 \mathrm{U}$ of Taq polymerase (Fermentas, Burlington, Canada) were used in the amplification reactions.

The reaction was programmed for initial denaturation at $94^{\circ} \mathrm{C}$ for 1 minute; followed by four cycles at $94^{\circ} \mathrm{C}$ for 5 minutes, $37^{\circ} \mathrm{C}$ for 5 minutes and $72^{\circ} \mathrm{C}$ for 5 minutes; 30 cycles at $94^{\circ} \mathrm{C}$ for 1 minute, $37^{\circ} \mathrm{C}$ for 1 minute and $72^{\circ} \mathrm{C}$ for 2 minutes; and final extension at $72^{\circ} \mathrm{C}$ for 10 minutes. Reaction products were loaded on $1.5 \%$ agarose gel and stained with ethidium bromide $(0.5 \mu \mathrm{g} / \mathrm{mL})$ after electrophoresis for 3 hours at 100V. 
A $1 \mathrm{~Kb}$ DNA ladder (Invitrogen Brasil,) was used as a size marker. RAPD-PCR profiles were defined according to the presence or absence, and intensity of polymorphic bands. Genetic patterns were compared by visual and automated analysis by using the UVIPro software (UVIbandmap version 11.9, UVITEC, Cambridge, UK). Cluster analysis was done by using the UPGMA method of the UVIPro software applying a maximum tolerance of $1.2 \%$ and the percentages of similarity were estimated by the Jaccard's coefficient. The reproducibility of the RAPD patterns was assessed by using the selected primers with different DNA samples isolated independently from the same strain amplified at different times.

\section{RESULTS AND DISCUSSION}

The investigation on the etiology of the microbiota in the milk and flies revealed that Escherichia coli was the sole bacterial species present in both biological specimens, found on farms 1, 2, 3, 4, 7, 9 and 10, for a total of $58 \mathrm{E}$. coli colonies. No other enterobacterial species was observed simultaneously in the stable flies and milk samples collected from a single farm. This can probably be explained by the fact that $E$. coli is the leading enterobacterium causing bovine mastitis, as reported in other studies (Lehtolainen 2003, Halasa et al. 2007). The observation of $E$. coli as the only species isolated both from milk and fly samples can be explained by the fact that this bacteria is most commonly implicated in episodes of environmental bovine mastitis, as commented by Blum et al. (2014).

In this study, six random primers were used (M13, $1247,1254,1253,1281$ and A04) and all of which had previously been utilized in E. coli population studies (Pacheco et al. 1997, Grif et al. 1998, Regua-Mangia et al. 2004). After initial amplification reactions, three of them (A04, 1254 and M13) were selected for RAPD typing since their profiles presented reproducibility, higher discriminatory power and distinct polymorphic bands.

RAPD typing revealed a genetically diverse bacterial population. Amplification reactions generated informative profiles composed of 4-21 polymorphic bands ranging from $320 \mathrm{bp}$ to $3500 \mathrm{bp}$ : primer A04 generated profiles ranging from 5 to 19 bands; primer 1254 profiles composed by 4 to 17 bands; and primer M13 profiles with 7 to 21 bands. The-

Table 1. Escherichia coli samples identified and its electrophoretic profile from mastitic udders from dairy farms of Barra Mansa and Resende municipalities, Rio de Janeiro State, Brazil

\begin{tabular}{ccccccc}
\hline Sample & Farm & Cow number & Udder teat & \multicolumn{3}{c}{ Electrophoretic profiles } \\
\cline { 5 - 7 } & & & & 1254 & A04 & M13 \\
\hline 2 & I & 3 & Rear left & 1 & 1 & 1 \\
3 & I & 5 & Front right & 1 & 1 & 1 \\
6 & II & 12 & Rear left & 4 & 4 & 4 \\
10 & III & 16 & Rear right & 8 & 8 & 8 \\
19 & IV & 24 & Front right & 15 & 15 & 15 \\
20 & IV & 24 & Rear right & 16 & 16 & 16 \\
21 & IV & 26 & Rear left & 16 & 16 & 16 \\
22 & IV & 27 & Front left & 16 & 16 & 16 \\
23 & IV & 28 & Rear right & 17 & 17 & 17 \\
31 & VII & 37 & Front right & 24 & 24 & 24 \\
32 & VII & 37 & Rear left & 24 & 24 & 24 \\
42 & IX & 43 & Front left & 31 & 31 & 32 \\
43 & IX & 43 & Front right & 31 & 31 & 32 \\
48 & IX & 49 & Front left & 35 & 35 & 36
\end{tabular}

re was no clear correlation between $C+G$ content and the ability of the primer to detect polymorphic. The reactions with primers A04 (60\%), 1254 (70\%) and M13 (66\%) generated 49, 49 and 50 distinct profiles, respectively (Table 1 and 2).

Identical RAPD genetic profiles were observed between bacterial $E$. coli isolates from distinct cows on a single farm. The circulation of common genetic patterns provides evidence of the circulation of specific lineages between herds which possibly occurred due to the low level of milking hy-

Table 2. Escherichia coli samples identified and its electrophoretic profile from anatomical sites of stable flies collected from dairy farms of Barra Mansa and Resende municipalities, Rio de Janeiro State, Brazil

\begin{tabular}{|c|c|c|c|c|c|c|}
\hline \multirow[t]{2}{*}{ Sample } & \multirow[t]{2}{*}{ Farm } & \multirow[t]{2}{*}{ Fly number } & \multirow[t]{2}{*}{ Anatomical site } & \multicolumn{3}{|c|}{ Electrophoretic profiles } \\
\hline & & & & 1254 & $\mathrm{~A} 04$ & M13 \\
\hline 4 & I & 4 & Body surface & 2 & 2 & 2 \\
\hline 5 & I & 18 & Body surface & 3 & 3 & 3 \\
\hline 7 & II & 3 & Body surface & 5 & 5 & 5 \\
\hline 8 & II & 9 & Body surface & 6 & 6 & 6 \\
\hline 9 & II & 16 & Mouth apparatus & 7 & 7 & 7 \\
\hline 11 & III & 10 & Body surface & 9 & 9 & 9 \\
\hline 12 & III & 12 & Body surface & 10 & 10 & 10 \\
\hline 13 & $\mathrm{~V}$ & 2 & Mouth apparatus & 11 & 11 & 11 \\
\hline 14 & $\mathrm{~V}$ & 13 & Body surface & 12 & 12 & 12 \\
\hline 15 & $\mathrm{~V}$ & 13 & Mouth apparatus & 13 & 13 & 13 \\
\hline 16 & V & 19 & $\begin{array}{c}\text { Abdominal } \\
\text { digestive tract }\end{array}$ & 13 & 13 & 13 \\
\hline 24 & IV & 1 & Body surface & 18 & 18 & 18 \\
\hline 25 & IV & 8 & Mouth apparatus & 19 & 19 & 19 \\
\hline 26 & IV & 16 & Body surface & 20 & 20 & 20 \\
\hline 28 & VI & 2 & $\begin{array}{c}\text { Abdominal } \\
\text { digestive tract }\end{array}$ & 21 & 21 & 21 \\
\hline 29 & VI & 7 & $\begin{array}{c}\text { Abdominal } \\
\text { digestive tract }\end{array}$ & 22 & 22 & 22 \\
\hline 30 & VI & 14 & Body surface & 23 & 23 & 23 \\
\hline 33 & VII & 10 & Body surface & 25 & 25 & 25 \\
\hline 34 & VII & 12 & Mouth apparatus & 26 & 26 & 26 \\
\hline 35 & VII & 14 & Body surface & 27 & 27 & 27 \\
\hline 36 & VII & 19 & Mouth apparatus & 28 & 28 & 28 \\
\hline 37 & VII & 19 & Body surface & 28 & 28 & 29 \\
\hline 38 & VIII & 14 & Body surface & 29 & 29 & 30 \\
\hline 39 & VIII & 14 & Mouth apparatus & 29 & 30 & 31 \\
\hline 40 & VIII & 14 & $\begin{array}{c}\text { Abdominal } \\
\text { digestive tract }\end{array}$ & 30 & 30 & 31 \\
\hline 41 & VIII & 20 & Body surface & 30 & 30 & 31 \\
\hline 44 & IX & 4 & Body surface & 32 & 32 & 33 \\
\hline 45 & IX & 14 & Mouth apparatus & 33 & 33 & 34 \\
\hline 46 & IX & 20 & Mouth apparatus & 34 & 34 & 35 \\
\hline 49 & $\mathrm{X}$ & 2 & $\begin{array}{c}\text { Abdominal } \\
\text { digestive tract }\end{array}$ & 36 & 36 & 37 \\
\hline 50 & $X$ & 3 & Mouth apparatus & 37 & 37 & 38 \\
\hline 51 & $\mathrm{X}$ & 5 & Body surface & 38 & 38 & 39 \\
\hline 52 & $\mathrm{X}$ & 6 & Mouth apparatus & 39 & 39 & 40 \\
\hline 53 & $\mathrm{X}$ & 7 & Mouth apparatus & 40 & 40 & 41 \\
\hline 54 & $X$ & 7 & $\begin{array}{c}\text { Abdominal } \\
\text { digestive tract }\end{array}$ & 41 & 41 & 42 \\
\hline 55 & $\mathrm{X}$ & 9 & Mouth apparatus & 42 & 42 & 43 \\
\hline 56 & $X$ & 10 & Body surface & 43 & 43 & 44 \\
\hline 57 & $\mathrm{X}$ & 11 & Body surface & 44 & 44 & 45 \\
\hline 58 & $X$ & 13 & Body surface & 45 & 45 & 46 \\
\hline 59 & $\mathrm{X}$ & 15 & Body surface & 46 & 46 & 47 \\
\hline 60 & $X$ & 17 & Body surface & 47 & 47 & 48 \\
\hline 61 & $X$ & 19 & $\begin{array}{c}\text { Abdominal } \\
\text { digestive tract }\end{array}$ & 48 & 48 & 49 \\
\hline 62 & $\mathrm{X}$ & 20 & Body surface & 49 & 49 & 50 \\
\hline
\end{tabular}


giene at the farms visited as verified by Kempf et al. (2016). Careless milking practices were often observed, without routine cleaning of the teats and hand washing by the farm workers, practices that favor the spread of bacteria as reported by De Vliegher et al. (2012). It was not possible to observe the use of prophylactic strategies as food supply to the cows after milking, to prevent them from lying down before closure of the streak canal, which, in turn allows the entrance of agents of mastitis in the mammary quarters. According to Oliver et al. (2001) and Lopes et al. (2012), prophylactic strategies decrease the prevalence of environmental and contagious mastitis.

Identical genetic patterns were shared by E. coli isolates from different parts of the same fly and from different flies, as observed with colonies from the body surface. This was possibly due to the presence of the bacterium in the environment used by the flies for development during their non-parasitic phases, as reported by Ahmad et al. (2007).

It was isolated $E$. coli strains from milk that exhibited identical electrophoretic profile from farms that shared certain characteristics, such as manual milking and precarious hygiene, with milking done in most cases in direct floor stalls. These results thus reinforce the reported by Costa Sobrinho et al. (2012) that the poor hygiene promotes the establishment and the circulation of microorganisms between animals of the herd, especially when good management practices are not commonly used.

Clustering analysis of RAPD-PCR based on Jaccard similarity index revealed a bacterial population arranged as single branches or clustered into small clonal groups (Figure 1). Closer relatedness was especially observed among $E$. coli strains isolated from the same mastitic milk samples. The clonal groups 1.02 and 1.03 represented E. coli isolated from Farm 1, from two different cows. The same occurred with sample 4.22, which exhibited identical RAPD genotypes compared to samples 4.20 and 4.21, isolated from different cows. Identical genetic profiles were also observed between E. coli samples 7.31 and 7.32 (Farm 7) and 9.42 and 9.43 (Farm 9) isolated from different quarters of a single cow.

RAPD clustering was not determined by the presence of substrates favoring the development of stable flies, feeding after milking and biochemical characteristics. Considering the clinical status, E.coli isolates obtained from the milk of cows with sub-clinical mastitis showed to be more closely related when compared with the E. coli from a cow with clinical mastitis. The overall chromosomal analysis of E. coli isolates from clinical and sub-clinical mastitis, revealed distinct genetic background which is consistent with previous observations with nonrelated epidemiological strains and thus characterizing distinct evolutionary lineages as suggested by Lamey et al. (2013). On the other hand, different patterns also was described by Ramasoota et al. (2000) between clinical samples and subclinical each other's.

E. coli isolates obtained from the fly parts showed a high diversity between electrophoretic profiles, suggesting the $E$. coli strains were acquired from the environment rather than clinical situations (Ahmad et al. 2007). It could be explained since the most genetically related samples were

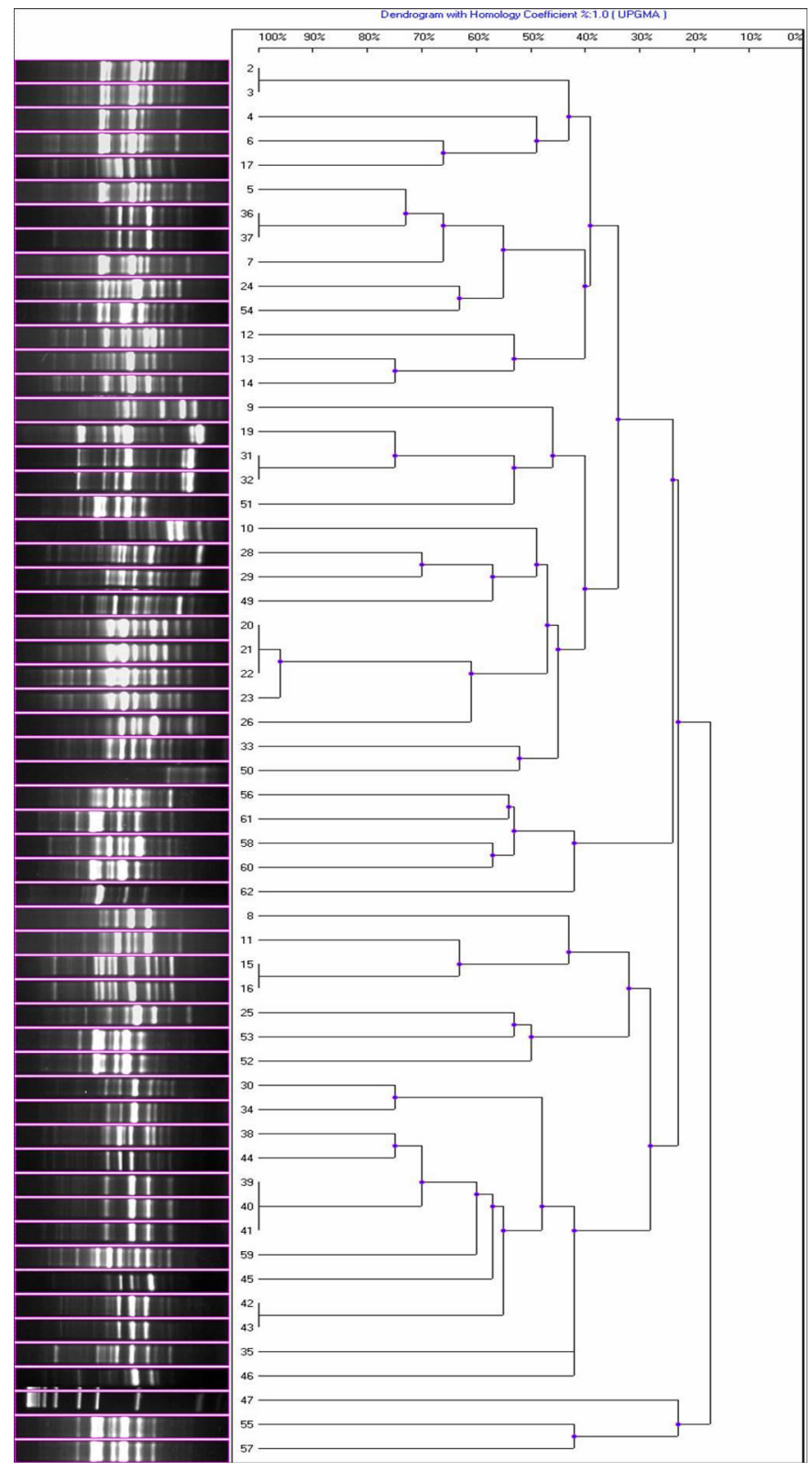

Fig.1.1254 primer dendrogram profile of Escherichia coli samples from stable fly and mastitic milk.

detected at farms without any special characteristic other than poor milking hygiene.

The high genetic diversity detected in the bacterial population studied suggests that the E. coli isolates from milk and fly parts are not clonal related have a non-clonal origin. This diversity was expected, since when dispersed in the environment, the occurrence of genetic exchange between different bacteria population can be enhanced. These microorganisms are subjected to adverse conditions (Costa Sobrinho et al. 2012, Lopes et al. 2012) instead of particular epidemiological situations, as shown by the fact there were no shared profiles between farms or the municipalities visited.

This is the first study evaluating the genetic relationship of $E$. coli sub-populations isolated from mastitic milk and from flies. In similar studies, some authors have repor- 
ted that muscidae are vectors of a determined pathogenic agent when similarity is observed in isolates from the stable fly and milk. However, there are no previous studies employing molecular tools to investigate genetic variability and clonal relationship of these sub-populations. Therefore, it is too early to state that the stable fly, or any other muscid, can be responsible for transmitting the bacteria in the environment (Moraes et al. 2004, Keen et al. 2006, Castro et al. 2007, Förster et al. 2009).

Our results highlight the possible role of the stable fly in spreading E. coli and reinforce the importance of controlling populations of this fly, in order to prevent the transmission of potentially pathogenic $E$. coli strains for humans and animals. This is of special concern, especially in farms where sanitation and training in animal management practices are required.

\section{REFERENCES}

Ahmad A., Nagaraja T.G. \& Zurek L. 2007. Transmission of Escherichia coli 0157:H7 to cattle by house flies. Prev. Vet. Med. 80:74-78.

Anderson K.L., Lyman R., Moury K., Ray D., Watson D.W. \& Correa M.T. 2012. Molecular Epidemiology of Staphylococcus aureus mastitits in dairy heifers. J. Dairy Sci. 95:4921-4930.

Blum S.E., Heller E.D. \& Leitner G. 2014. Long term effects of Escherichia coli mastitis. Vet. J. 201:72-77.

Bowman D.D. 2014. Georgis' Parasitology for Veterinarians. 4th ed. Sauders Elsevier, Missouri. 432p.

Bramley A.J., Hillerton J.E., Higgs T.M. \& Hogben E.M. 1985. The carriage of summer mastitis pathogens by muscid flies. Brit. Vet. J. 141:618-627.

Braverman Y., Chizov-Ginzburg A., Saran A. \& Winkler M. 1999. The role of house flies (Musca domestica) in harboring Corynebacterium pseudotuberculosis in dairy herds in Israel. Rev. Sci. Tech. Off. Int. Epiz. 18:681-690.

Castro B.G., Pires S.D., Almeida B.M., Azevedo F.D., Moraes A.P.R., Flausino G., Oliveira A. \& Bittencourt A.J. 2001. Avaliação da capacidade de transmissão de bactérias causadoras de mastite por Stomoxys calcitrans (L.) em bovinos leiteiros. J. Bras. Patol. 37:173.

Castro B.G., Souza M.M.S. \& Bittencourt A.J. 2007. Aerobic Bacterial Microbiota in Stomoxys calcitrans: preliminary studies in Brazil. Revta Bras. Parasitol. Vet. 16:193-197.

Castro B.G., Souza M.M.S., Regua-Mangia A.H. \& Bittencourt A.J. 2013. Occurrence of Shiga-toxigenic Escherichia coli in Stomoxys calcitrans (Diptera: Muscidae). Revta Bras. Parasitol. Vet. 22:318-321.

Chirico J., Jonsson P., Kjellberg S. \& Thomas G. 1997. Summer mastitis experimentally induced by Hidrotaea irritans exposed to bacteria. Med. Vet. Entomol. 11:187-192.

Costa Sobrinho P.S., Faria C.A.M., Pinheiro J.S., Almeida H.G., Pires C.V. \& Santos A.S. 2012. Bacteriological quality of raw milk used for production of a Brazilian farmstead raw milk cheese. Foodborne Pathog. Dis. 9:138-144.

De Vliegher S., Fox L.K., Piepers S., McDougall S. \& Barkema H.W. 2012 Mastitis in dairy heifers: nature of the disease, potential impact, prevention, and control. J. Dairy Sci. 95:1025-1040.

Fairbrother J.H., Dufor S., Fairbrother J.M., Francoz D., Nadeau E. \& Messier S. 2015. Characterization of persistent and transient Escherichia coli isolates recovered from clinical mastitis episodes in dairy cows. Vet. Microbiol. 176:126-133.

Ferreira J.L., Freitas J.L., Lins H.A., Cavalcante T.V., Macedo N.A. \& Borjas A.R. 2007. Prevalência e etiologia da mastite bovina no município de Teresina, Piauí. Ciênc. Anim. Bras. 8:261-266.

Förster M., Sievert K., Messler S. \& Pfeffer K. 2009. Comprehensive study on the occurrence and distribution of pathogenic microorganisms carried by synanthropic flies caught at different rural locations in Germany. J. Med. Entomol. 46:1164-1166.
Grif K., Karch H., Schneider C. \& Daschner F.D. 1998. Comparative study of five different techniques for epidemiological typing of Escherichia coli 0157 - Phenotypic methods and genotypic subtyping. Diagn. Microbiol. Infect. Dis. 32:165-176.

Halasa T., Huijps K., Osteras O. \& Hogeveen H. 2007. Economic effects of bovine mastitis and mastitis management: a review. Vet Quart. 29:1831.

Hertl J.A., Leach J.D., Bar D., Bennett G.J., Rauch B.J., Welcome F.L., Tauer L.W. \& Schukken Y.H. 2010. Effects of clinical mastitis caused by gram-positive and gram-negative bacteria and other organisms on the probability of conception in New York State Holstein dairy cows. J. Dairy Sci. 93:1551-1560.

Hillerton J.E. \& Bramley A.J. 1985. Carriage of Corynebacterium pyogenes by cattle nuisance flies Hydrotaea irritans (Fallen) and Musca autumnalis (De Geer). Vet. Parasitol. 18:223-228.

IBGE 2009. Pesquisa Pecuária Municipal 2009. Fundação Instituto Brasileiro de Geografia e Estatística. Disponível em <http://www.ibge.gov. br/> Acesso em 5 mai. 2015.

Keen J.E., Wittum T.E., Dunn J.R., Bono J.L. \& Durso L.M. 2006. Shiga-toxigenic Escherichia coli 0157 in agricultural fair livestock, United States. Emerg. Infect. Dis. 12:780-786.

Kempf F., Slugocki C., Blum S.E., Leitner G. \& Germon P. 2016. Genomic Comparative Study of Bovine Mastitis Escherichia coli PLoS One 11:435449.

Koneman E.W., Janda S.D., Schreckenberger W.M. \& Winn J.R.P.C. 2008. Diagnóstico Microbiológico. 6th ed. MEDSI, Rio de Janeiro. 1465p.

Lamey A.S., Ammar A.M., Zaki E.R., Khairy N., Moshref B.F. \& Refai M.K. 2013. Virulence Factors of Escherichia coli Isolated from Recurrent Cases of Clinical and Subclinical Mastitis in Buffaloes. Intl. J. Microbiol. Res. 4:86-94.

Lehtolainen T., Pohjanvirta T., Pyörälä S. \& Pelkonen S. 2003. Association between virulence factors and clinical course of Escherichia coli mastitis. Acta Vet. Scand. 44:203-205.

Lopes M.A., Demeu F.A., Da Rocha C.M.B.M., Da Costa G.M., Franco Neto A. \& Dos Santos G. 2012. Avaliação do impacto econômico da mastite em rebanhos bovinos leiteiros. Arqs Inst. Biológico, São Paulo, 79:477483.

Moraes A.P.R., Badini P.V., Souza M.M.S. \& Bittencourt A.J. 2004. Avaliação da capacidade de Stomoxys calcitrans (Linnaeus, 1758) em carrear bactérias envolvidas nas etiologias das mastites de municípios do Rio de Janeiro. Revta Bras. Parasitol. Vet. 13:143-149.

Nevala M., Taponen S. \& Pyörälä S. 2004. Bacterial etiology of clinical mastitis: data from Saari Clinic Ambulatory in 2003-2004. Finn. Vet. J. 110:363-369.

Oliver S.P. 2001. Influence of subclinical mastitis during early lactation on reproductive parameters. J. Dairy Sci. 84:1407-1412.

Pacheco A.B.F., Guth B.E.C., Soares K.C.C., Nishimura L., Almeida D.F. \& Ferreira L.C.S. 1997. Random amplification of polymorphic DNA reveals serotype-specific clonal clusters among enterotoxigenic Escherichia coli strains isolated from humans. J. Clin. Microbiol. 35:1521-1525.

Puri-Giri R., Ghosh A. \& Zurek L. 2015. Stable Flies (Stomoxys calcitrans L.) from confined beef cattle do not carry Shiga-toxigenic Escherichia coli (STEC) in the digestive tract. Foodborne Pathog. Dis. Ahead of Print. Disponível <http://online.liebertpub.com/doi/pdfplus/10.1089/fpd. 2015.2056> Acesso em 31 jan. 2015.

Pyörälä S. 2002. New strategies to prevent mastitis. Reprod. Domest. Anim. 37:211-216.

Ramasoota P., Krovacek K., Chansiripornchai N., Mörner A.P. \& Svenson S.B. 2000. Identification of Escherichia coli recovered from milk of sows with coliform mastitis by random amplified polymorphic DNA (RAPD) using standardized reagents. Acta Vet. Scand. 41:249-259.

Regua-Mangia A.H., Guth B.C., Andrade J.R.C., Irino K., Pacheco A.B.F., Ferreira L.C.S., Zahner V. \& Teixeira L.M. 2004. Genotypic and phenotypic characterization of enterotoxigenic Escherichia coli (ETEC) strains isolated in Rio de Janeiro city, Brazil. FEMS Immunol. Med. Microbiol. 40:155-162. 
Ryman V.E., Nickerson S.C., Hurley D.J., Berghaus R.D. \& Kautz F.M. 2013. Influence of horn flies (Haematobia irritans) on teat skin condition, intramammary infection, and serum anti-S. aureus antibody titres in holstein heifers. Res. Vet. Sci. 95:343-346.

Shpigel N.Y., Elazar S. \& Rosenshine I. 2008. Mammary pathogenic Escherichia coli. Curr. Opin. Microbiol. 11:60-65.
Shpigel N.Y., Winkler M., Ziv G. \& Saran A. 1998. Clinical, bacteriological and epidemiological aspects of clinical mastitis in Israeli dairy herds. Prev. Vet. Med. 35:1-9.

Vogel L., Oorschot E., Maas H.M.E., Minderhoud B. \& Dijkshoorn L. 2000. Epidemiologic typing of Escherichia coli using RAPD analysis, robotyping and serotyping. Clin. Microbiol. Infect. 6:82-87. 